\title{
Hydrogenophilus thermoluteolus gen. nov., sp. nov., a thermophilic, facultatively chemolithoautotrophic, hydrogen-oxidizing bacterium
}

\author{
Nobuhiro R. Hayashi, ${ }^{1}$ Tatsuya Ishida, ${ }^{2}$ Akira Yokota, ${ }^{2}$ Tohru Kodama ${ }^{3}$ \\ and Yasuo Igarashi ${ }^{1}$
}

Author for correspondence: Yasuo Igarashi. Tel: +81338122111 ext. 5142 . Fax: +81 356845196. e-mail: aigara@hongo.ecc.u-tokyo.ac.jp

\footnotetext{
1 Department of Biotechnology, University of Tokyo, Yayoi 1-1-1, Bunkyo-ku, Tokyo 1138657, Japan

2 Institute of Molecular and Cellular Biosciences, University of Tokyo, Yayoi 1-1-1, Bunkyo-ku, Tokyo 113-0032, Japan

${ }^{3}$ Faculty of Textile Science and Technology, Shinshu University, Tokida 3-15-1, Ueda-City, Nagano 3860018, Japan
}

The taxonomic positions of 'Pseudomonas hydrogenothermophila' strain TH-1 and 'Flavobacterium autothermophilum' strain TH-4 were studied by 165 rDNA sequencing. These organisms are Gram-negative, strictly aerobic, thermophilic, facultatively chemolithoautotrophic hydrogen-oxidizing rods and have a DNA G+C content of 63-65 mol\%. The major isoprenoid quinone is ubiquinone-8 and 3-hydroxy decanoic acid (3-OH $\mathrm{C}_{10: 0}$ ) is the major 3-hydroxy cellular fatty acid. A phylogenetic analysis based on 165 rDNA sequences placed strains TH-1' and TH-4 in the $\beta$-subclass of the Proteobacteria. The taxonomic characteristics of these organisms are different from those of previously described aerobic, facultatively chemolithoautotrophic, hydrogen-oxidizing bacteria that belong to the $\beta$-subclass of Proteobacteria. On the basis of the information described above, a new genus and species, Hydrogenophilus thermoluteolus gen. nov., sp. nov., is described to include both strains. The type strain is strain TH-1T (= IFO 14978').

Keywords: Hydrogenophilus thermoluteolus gen. nov., sp. nov., hydrogen-oxidizing bacterium, thermophile, 16S rRNA

\section{INTRODUCTION}

Many aerobic, hydrogen-oxidizing (Knallgas) bacteria have been isolated and identified as Gram-negative or Gram-positive organisms (Schlegel, 1989). These include unique genera, Hydrogenobacter (Kawasumi et al., 1984; Shima \& Suzuki, 1993), Calderobacterium (Kryukov et al., 1983), Aquifex (Huber et al., 1992) and Hydrogenovibrio (Nishihara et al., 1991). Five facultatively chemolithoautotrophic, hydrogenoxidizing Pseudomonas species have been reclassified as members of the genus Hydrogenophaga (Willems et al., 1989).

Two aerobic, hydrogen-oxidizing bacteria, strains TH$1^{\mathrm{T}}$ and $\mathrm{TH}-4$, were isolated from the soil around a hot spring (Goto et al., 1977). These strains are facultative chemolithoautotrophs that are able to grow not only autotrophically using $\mathrm{H}_{2}, \mathrm{O}_{2}$ and $\mathrm{CO}_{2}$, but also

The EMBLDDBJ/GenBank accession numbers for the sequences reported in this paper are AB009828 (strain $\mathrm{TH}^{1} \mathbf{1}^{\mathrm{T}}$ ) and AB009829 (strain $\mathrm{TH}-4$ ). heterotrophically in organic media. The optimum temperatures for the growth of strains $\mathrm{TH}-1^{\mathrm{T}}$ and TH4 are 52 and $50{ }^{\circ} \mathrm{C}$, respectively. The properties of both strains have been described previously. In early taxonomic studies, strains $\mathrm{TH}-\mathrm{1}^{\mathrm{T}}$ and $\mathrm{TH}-4$ were identified as 'Pseudomonas hydrogenothermophila' and 'Flavobacterium autothermophilum', respectively (Goto et al., 1978). However, more recent studies on their cellular fatty acid composition and isoprenoid quinone composition revealed that both strains $\mathrm{TH}-1^{\mathrm{T}}$ and $\mathrm{TH}-4$ belonged to ' $P$. hydrogenothermophila' (Takeuchi \& Yokota, 1991). In the present study, the 16S rDNA sequences of the two strains have been determined and we propose a new genus and species, Hydrogenophilus thermoluteolus gen. nov., sp. nov., for the strains TH$1^{\mathrm{T}}$ and TH-4 on the basis of the phylogenetic and chemotaxonomic results.

\section{METHODS}

Bacterial strains. Strains TH- $1^{\mathrm{T}}\left(=\mathrm{IFO} 14978^{\mathrm{T}}\right)$ and TH-4 (= IFO 14593) were isolated from soil around a hot spring in Izu peninsula, Shizuoka Prefecture, Japan (Goto et al., 
1977). Alcaligenes faecalis strain IAM $12369^{\mathrm{T}}$, used as a negative control for DNA-DNA hybridization, was obtained from the IAM culture collection.

Morphological characteristics. The cell morphology of strain $\mathrm{TH}-1^{\mathrm{T}}$ was studied by using cells grown under heterotrophic conditions with malate (Goto et al., 1978). The sample used for scanning electron microscopy was prepared by fixing cells with $1 \%$ glutaraldehyde, dehydrating the cells with a graded acetone series, freeze-drying and finally sputtercoating the preparation with platinum under a vacuum (E1030 Ion sputter; Hitachi). Electron microscopy was performed with a Hitachi S-4500 scanning electron microscope.

Isolation of DNA and sequencing. The methods used for the isolation of DNA for $16 \mathrm{~S}$ rDNA cloning, DNA sequencing and sequence data analysis were described previously (Ishida et al., 1997). Strains TH- $1^{\mathrm{T}}$ and TH-4 and $A$. faecalis were cultivated in $2 \times$ YT broth (Sambrook et al., 1989) and DNA was isolated as described previously (Yokoyama et al., 1995) for DNA-DNA hybridization. The primers used for PCR amplification of $16 \mathrm{~S}$ rDNA were: forward primer, $8 \mathrm{~F}$ (5' AGAGTTTGATCCTGGCTCAG $3^{\prime}$ ); and reverse primer, 1512R (5' ACGGCTACCTTGTTACGACT 3') (Escherichia coli numbering system). Recombinant DNA manipulation was carried out as described by Sambrook $e t$ al. (1989).

DNA-DNA hybridization. Levels of DNA relatedness were determined by the method of Ezaki et al. (1989).

Phylogenetic analysis. The new 16S rDNA sequences of the two strains were multiply aligned using CLUSTAL $\mathrm{W}$ version 1.6 (Thompson et al., 1994) with a selection of reference sequences of Proteobacteria obtained from the DDBJ, EMBL, GenBank and Ribosomal Database Project (RDP) databases. The multiple sequence alignment was then corrected manually as necessary. A phylogenetic tree was constructed from evolutionary distance data by applying the algorithm of the neighbour-joining method (Saitou \& Nei, 1987 ) to $K_{\text {nuc }}$ values (Kimura, 1980). To evaluate the robustness of the branches of the inferred tree, the bootstrap resampling method of Felsenstein (1985) was used with 1000 replicates.

\section{RESULTS AND DISCUSSION}

\section{Morphology}

The morphologies of strains $\mathrm{TH}-1^{\mathrm{T}}$ and $\mathrm{TH}-4$ have been described previously (Goto et al., 1978). The present study contributes the result of an electron micrograph to the morphological study of strain TH$1^{\mathrm{T}}$. Cells of $\mathrm{TH}-1^{\mathrm{T}}$ showed a straight-rod form and were about $0.5 \mu \mathrm{m}$ in diameter and $2.0 \mu \mathrm{m}$ in length (Fig. 1). This result agrees with the previous report on its morphological characteristics (Goto et al., 1978). Previously, TH- ${ }^{\mathrm{T}}$ was reported to be motile, but motility was not observed in cells of strain $\mathrm{TH}-1^{\mathrm{T}}$ in this study. Strain TH-4 was not motile.

\section{Phylogenetic analysis}

Almost complete 16S rDNA sequences of strains TH$\mathrm{I}^{\mathrm{T}}$ and TH-4 (1461 nucleotides) were determined. The sequence of strain $\mathrm{TH}-1^{\mathrm{T}}$ showed high identity $(99 \cdot 5 \%)$ to that of strain TH-4. The phylogenetic tree con-

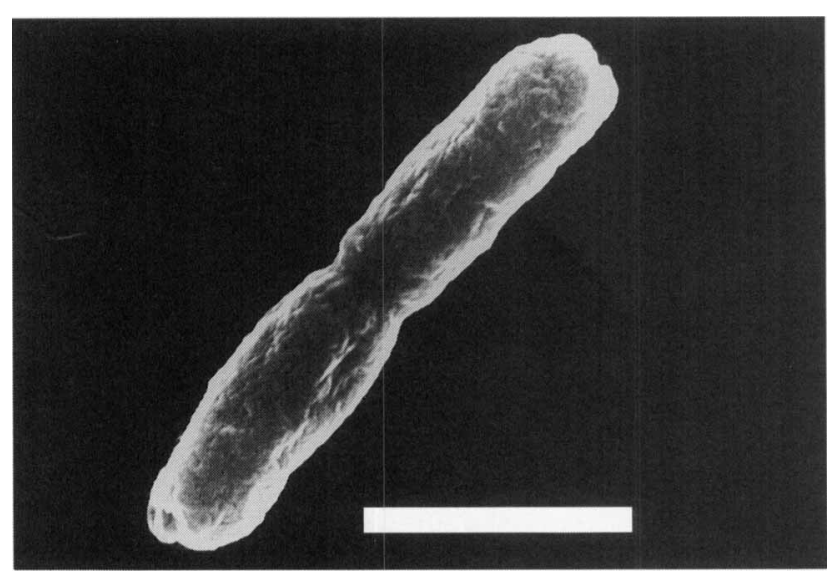

Fig. 1. Scanning electron micrograph of strain $\mathrm{TH}^{-1}{ }^{\top}$. Bar, $1 \mu \mathrm{m}$.

structed by the neighbour-joining method and $K_{\text {nuc }}$ values showed that these strains belonged to the $\beta$ subclass of the Proteobacteria. These results agree with the studies of the polyamine distribution pattern (Hamana et al., 1991). Subsequently, the results of a comparison with the sequences of representative genera of the $\beta$-subclass showed that the sequences of the two strains were not closely related to those of members of any other genera. The tree clearly indicated that the two strains formed a novel lineage and a deep branch within the $\beta$-subclass of the Proteobacteria (Fig. 2). The two strains seemed to be a new genus among the members of $\beta$-subclass of the Proteobacteria.

DNA-DNA hybridization experiments demonstrated that strain $\mathrm{TH}-1^{\mathrm{T}}$ showed $89 \%$ DNA relatedness to strain TH-4. These results indicated that the strains belonged to the same genus and the same species.

Major properties of the two strains were compared with those of facultatively chemolithoautotrophic, hydrogen-oxidizing bacteria in the $\beta$-subclass of the Proteobacteria. The genus Hydrogenophaga includes mesophilic, facultatively chemolithoautotrophic, hydrogen-oxidizing bacteria, and four species are included in this genus, which were transferred from the genus Pseudomonas (Hydrogenophaga flava, formerly Pseudomonas flava; Hydrogenophaga palleronii, formerly Pseudomonas palleronii; Hydrogenophaga pseudoflava, formerly Pseudomonas pseudoflava and 'Pseudomonas carboxydoflava'; and Hydrogenophaga taeniospiralis, formerly Pseudomonas taeniospiralis) (Willems et al., 1989). Alcaligenes latus and Alcaligenes eutrophus are aerobic, hydrogen-oxidizing bacteria (Aragno \& Schlegel, 1992), although Alcaligenes eutrophus has been reclassified as Ralstonia eutropha (Yabuuchi et al., 1995). Acidovorax delafieldii and Acidovorax facilis, which formerly belonged to the genus Pseudomonas, are facultatively hydrogen-oxidizing bacteria (Willems et al., 1990). Aquaspirillum autotrophicum is also known to be a facultatively 


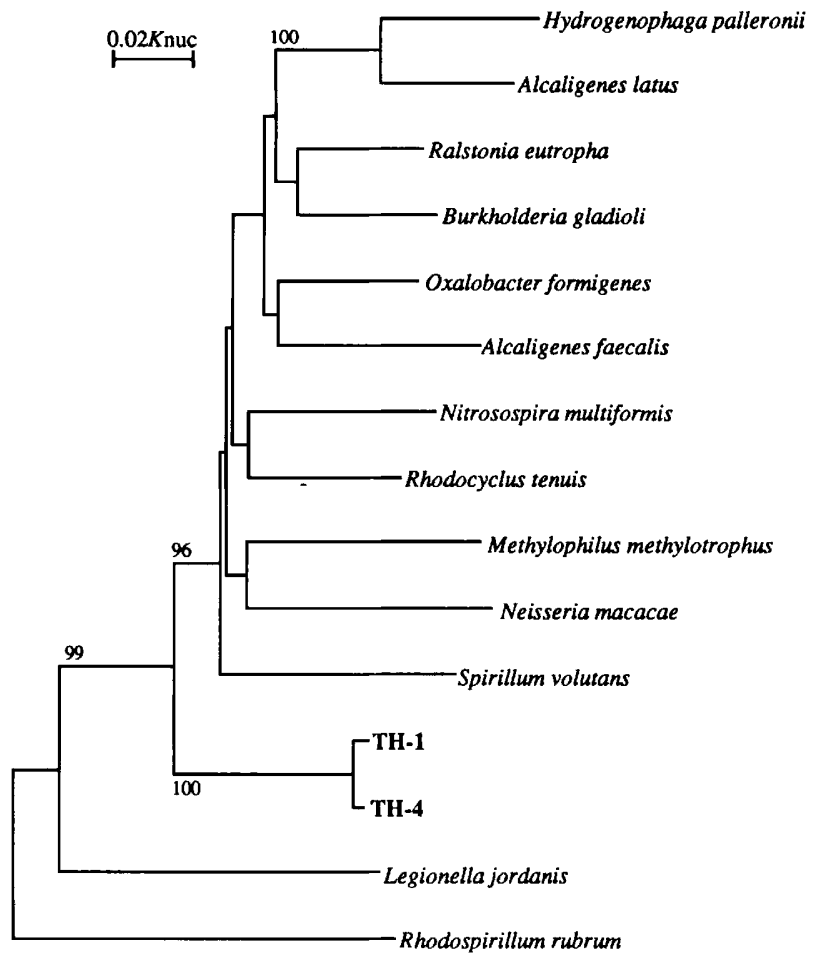

Fig. 2. Phylogenetic tree based on 165 rDNA sequences, constructed by neighbour-joining, with Rhodospirillum rubrum as the outgroup. Strains $\mathrm{TH}-1^{\top}$ and $\mathrm{TH}-4$ are indicated in bold. The total number of nucleotides compared was 1135 . Numbers on the branches are confidence limits (expressed as percentages) estimated by a bootstrap analysis performed with 1000 replicates. Confidence limits less than $80 \%$ are not shown. Accession numbers (EMBL/DDBJ/GenBank) of sequences used for phylogenetic analysis of 165 rDNA are: Alcaligenes faecalis ATCC 8750', M22508; Alcaligenes latus IAM 12599', D88007; Burkholderia gladioli ATCC 10248 ${ }^{\top}, \mathrm{X}^{2} \mathrm{67038}$; Hydrogenophaga palleronii DSM $63^{\top}$, AF019073; Legionella jordanis ATCC $33623^{\top}$ ( $y$-subclass), X73396; Methylophilus methylotrophus ATCC 53528', L15475; Neisseria macacae ATCC 33926', L06169; Nitrosospira multiformis ATCC 25196', L35509; Ralstonia eutropha ATCC 17697', M32021; Rhodocyclus tenuis ATCC 25093', D16208; Rhodospirillum rubrum ATCC $11170^{\top}(\alpha-$ subclass), D30778; Spirillum volutans ATCC 19554T, M34131. Data for Oxalobacter formigenes ATCC $35274^{\top}$ was obtained from the RDP, release number 5.0. All bacteria in this figure except for $L$. jordanis and Rhodospirillum rubrum belong to the $\beta$-subclass of Proteobacteria.

chemolithoautotrophic, hydrogen-oxidizing bacterium (Aragno \& Schlegel, 1992). Strains TH-1 ${ }^{\mathrm{T}}$ and TH-4 are different from the genera Hydrogenophaga, Alcaligenes and Ralstonia in the terms of carbonsource utilization and major-fatty-acid composition (Aragno \& Schlegel, 1992; Busse \& Auling, 1992; Oyaizu-Masuchi \& Komagata, 1988; Urakami et al., 1995; Willems et al., 1989). The phylogenetic positions of Hydrogenophaga, Alcaligenes and Ralstonia are quite different from those of strains TH- $1^{\mathrm{T}}$ and TH-4 (Fig. 2). While Acidovorax delafieldii, Acidovorax facilis and Aquaspirillum autotrophicum have not been subjected to phylogenetic studies based on nearly complete 16S rDNA sequences, an rRNA-cistron- similarity dendrogram study indicated that Acidovorax is phylogenetically close to Hydrogenophaga (Willems et al., 1990). Strains TH- $1^{\mathrm{T}}$ and $\mathrm{TH}-4$ were different from Acidovorax delafieldii and Acidovorax facilis in terms of carbon-source utilization and major-fattyacid composition (Aragno \& Schlegel, 1992; Willems et al., 1990) and were different from Aquaspirillum autotrophicum in term of cell morphology (Aragno \& Schlegel, 1992).

At least five species, Bacillus schlegelii, Bacillus tusciae, Hydrogenobacter thermophilus, Calderobacterium hydrogenophilum and 'Pseudomonas thermophila', have been reported to be thermophilic, aerobic, hydrogen-oxidizing bacteria (Aragno, 1992). Strains TH- $1^{\mathrm{T}}$ and $\mathrm{TH}-4$ have high optimum temperatures for growth but are taxonomically and phylogenetically quite different from these species.

On the basis of the findings described above, we propose that strains $\mathrm{TH}-1^{\mathrm{T}}$ and $\mathrm{TH}-4$ should be placed in a new genus as Hydrogenophilus thermoluteolus gen. nov., sp. nov.

\section{Description of Hydrogenophilus gen. nov.}

Hydrogenophilus (Hy.dro.ge.no'phi.lus. Gr. n. hydor water; Gr. v. genein to produce; M.L. neut. n. hydrogenum hydrogen (that which produces water); Gr. adj. philo loving, friendly to; M.L. masc. n. Hydrogenophilus hydrogen lover.

Cells are straight rods, Gram-negative and nonsporulating. Chemolithoautotrophic, using molecular hydrogen as an electron donor and carbon dioxide as a carbon source. Carbon dioxide is fixed via the Calvin-Benson cycle. The $\mathrm{G}+\mathrm{C}$ content of the DNA is about $63-65 \mathrm{~mol} \%\left(T_{\mathrm{m}}\right)$. Straight-chain saturated $\mathrm{C}_{16: 0}$ and $\mathrm{C}_{18: 0}$ acids are the major components of the cellular fatty acids and 3-OH $\mathrm{C}_{10: 0}$ is the major 3hydroxy cellular fatty acid. Ubiquinone- 8 is the major component of the quinone system.

\section{Description of Hydrogenophilus thermoluteolus sp. nov.}

Hydrogenophilus thermoluteolus (ther.mo.lu.te'o.lus. Gr. adj. thermos hot; L. adj. n. luteolus light-yellow; M.L. masc. adj. thermoluteolus hot and light-yellow).

Exponentially growing cells are $0 \cdot 5-0 \cdot 6 \times 2 \cdot 0-3 \cdot 0 \mu \mathrm{m}$ and occur singly. Colonies are dull yellow. Heterotrophic, using acetate, propionate, butyrate, succinate, DL-lactate, pyruvate and $\alpha$-ketoglutarate as electron donors and carbon sources. Ammonium ions, nitrate ions and urea are utilized solely as nitrogen sources but nitrite ions and gaseous nitrogen are not. The optimum temperature for growth is about $50-52{ }^{\circ} \mathrm{C}$. The optimum $\mathrm{pH}$ for growth is around 7.0. Isolated from soil around a hot spring in Izu peninsula, Shizuoka Prefecture, Japan. The type strain is strain $\mathrm{TH}-1^{\mathrm{T}}(=$ IFO $14978^{\mathrm{T}}$ ). 


\section{ACKNOWLEDGEMENTS}

This work was supported in part by a Grant-in-Aid for Science Research from the Ministry of Education, Science and Culture of Japan and by a grant from the Japan Society for the Promotion of Science. We thank Ms Yoshie Miyaji for taking the scanning electron micrograph.

\section{REFERENCES}

Aragno, M. (1992). Thermophilic, aerobic, hydrogen-oxidizing (Knallgas) bacteria. In The Prokaryotes, 2nd edn, pp. 3917-3933. Edited by A. Balows, H. G. Trüper, M. Dworkin, W. Harder \& K.-H. Schleifer. New York: Springer Verlag.

Aragno, M. \& Schlegel, H. G. (1992). The mesophilic hydrogenoxidizing (Knallgas) bacteria. In The Prokaryotes, 2nd edn, pp. 344-384. Edited by A. Balows, H. G. Trüper, M. Dworkin, W. Harder \& K.-H. Schleifer. New York: Springer Verlag.

Busse, H.-J. \& Auling, G. (1992). The genera Alcaligenes and 'Achromobacter'. In The Prokaryotes, 2nd edn, pp. 2544-2555. Edited by A. Balows, H. G. Trüper, M. Dworkin, W. Harder \& K.-H. Schleifer. New York: Springer Verlag.

Ezaki, T., Hashimoto, Y. \& Yabuuchi, E. (1989). Fluorometric deoxyribonucleic acid-deoxyribonucleic acid hybridization in microdilution wells as an alternative to membrane filter hybridization in which radioisotopes are used to determine genetic relatedness among bacterial strains. Int J Syst Bacteriol 39, 224-229.

Felsenstein, J. (1985). Confidence limits on phylogenies: an approach using the bootstrap. Evolution 39, 783-791.

Goto, E., Kodama, T. \& Minoda, Y. (1977). Isolation and culture conditions of thermophilic hydrogen bacteria. Agric Biol Chem 41, 685-690.

Goto, E., Kodama, T. \& Minoda, Y. (1978). Growth and taxonomy of thermophilic hydrogen bacteria. Agric Biol Chem 42, 1305-1308.

Hamana, K., Matsuzaki, S., Niitsu, M., Samejima, K., Igarashi, Y. \& Kodama, T. (1991). Distribution of hydroxypolyamines, aminopropylcadaverine, and spermine in thermophilic, hydrogen-oxidizing pseudomonads. $J$ Gen Appl Microbiol 37, 431-437.

Huber, R., Wilharm, T., Huber, D., Trincone, A., Burggaf, S., König, H., Rachel, R., Rockinger, I., Fricke, H. \& Stetter, K. O. (1992). Aquifex pyrophilus gen. nov., sp. nov., represents a novel group of marine hyperthermophilic hydrogen-oxidizing bacteria. Syst Appl Microbiol 15, 340-351.

Ishida, T., Yokota, A. \& Sugiyama, J. (1997). Phylogenetic relationships of filamentous cyanobacterial taxa inferred from 16S rRNA sequence divergence. J Gen Appl Microbiol 43, 237-241

Kawasumi, T., Igarashi, Y., Kodama, T. \& Minoda, Y. (1984). Hydrogenobacter thermophilus gen. nov., sp. nov., an extremely thermophilic, aerobic, hydrogen-oxidizing bacterium. Int J Syst Bacteriol 34, 5-10.

Kimura, M. (1980). A simple method for estimating evolutionary rates of base substitutions through comparative studies of nucleotide sequences. $J$ Mol Evol 16, 111-120.

Kryukov, V. R., Savel'eva, N. D. \& Pusheva, M. A. (1983). Calderobacterium hydrogenophilum gen. et sp. nov., an extremely thermophilic hydrogen bacterium and its hydrogenase activity.
Microbiology 52, 611-618 (English translation of Mikrobiologiya).

Nishihara, H., Igarashi, Y. \& Kodama, T. (1991). Hydrogenovibrio marinus gen. nov., sp. nov., a marine obligately chemolithoautotrophic hydrogen-oxidizing bacterium. Int $J$ Syst Bacteriol 41, 130-133.

Oyaizu-Masuchi, Y. \& Komagata, K. (1988). Isolation of freeliving nitrogen-fixing bacteria from the rhizosphere of rice. $J$ Gen Appl Microbiol 34, 127-164.

Saitou, N. \& Nei, M. (1987). The neighbor-joining method: a new method for reconstructing phylogenetic trees. Mol Biol Evol 4, 406-425.

Sambrook, J., Fritsch, E. F. \& Maniatis, T. (1989). Molecular Cloning : a Laboratory Manual, 2nd edn. Cold Spring Harbor, NY: Cold Spring Harbor Laboratory.

Schlegel, H. G. (1989). Aerobic hydrogen-oxidizing (Knallgas) bacteria. In Autotrophic Bacteria, pp. 305-329. Edited by H. G. Schlegel \& B. Bowien. Madison, WI: Science Tech.

Shima, S. \& Suzuki, K.-I. (1993). Hydrogenobacter acidophilus sp. nov, a thermoacidophilic, aerobic, hydrogen-oxidizing bacterium requiring elemental sulfur for growth. Int J Syst Bacteriol 43, 703-708.

Takeuchi, M. \& Yokota, A. (1991). Reclassification of strains of Flavobacterium-Cytophaga group in IFO culture collection. Inst Ferment Res Commun (Osaka) 15, 83-96.

Thompson, J. D., Higgins, D. G. \& Gibson, T. J. (1994). CLUSTAL $\mathrm{W}$ : improving the sensitivity of progressive multiple sequence alignment through sequence weighting, position-specific gap penalties and weight matrix choice. Nucleic Acids Res 22 , 4673-4680.

Urakami, T., Araki, H. \& Komagata, K. (1995). Characteristics of newly isolated $X$ anthobacter strains and fatty acid compositions and quinone system in yellow-pigmented hydrogen-oxidizing bacteria. Int J Syst Bacteriol 45, 863-867.

Willems, A., Busse, J., Goor, M., Pot, B., Falsen, E., Jantzen, E., Hoste, B., Gillis, M., Kersters, K., Auling, G. \& De Ley, J. (1989). Hydrogenophaga, a new genus of hydrogen-oxidizing bacteria that includes Hydrogenophaga flava comb. nov. (formerly Pseudomonas flava), Hydrogenophaga palleronii (formerly Pseudomonas palleronii), Hydrogenophaga pseudoflava (formerly Pseudomonas pseudoflava and 'Pseudomonas carboxydoflava'), and Hydrogenophaga taeniospiralis (formerly Pseudomonas taeniospiralis). Int J Syst Bacteriol 39, 319-333.

Willems, A., Falsen, E., Pot, B., Jantzen, E., Hoste, B., Vandamme, P., Gillis, M., Kersters, K. \& De Ley, J. (1990). Acidovorax a new genus for Pseudomonas facilis, Pseudomonas delafieldii, E. Falsen (EF) group 13, EF group 16, and several clinical isolates, with the species Acidovorax facilis comb. nov., Acidovorax delafieldii comb. nov., and Acidovorax temperans sp. nov. Int $J$ Syst Bacteriol 40, 384-398.

Yabuuchi, E., Kosako, Y., Yano, I., Hotta, H. \& Nishiuchi, Y. (1995). Transfer of two Burkholderia and an Alcaligenes species to Ralstonia gen. nov.: proposal of Ralstonia pickettii (Ralston, Palleroni and Doudoroff 1973) comb. nov., Ralstonia solanacearum (Smith 1896) comb. nov. and Ralstonia eutropha (Davis 1969) comb. nov. Microbiol Immunol 39, 897-904.

Yokoyama, K., Hayashi, N. R., Arai, H., Chung, S.-Y., Igarashi, Y. \& Kodama, T. (1995). Genes encoding RubisCO in Pseudomonas hydrogenothermophila are followed by a novel $c b b Q$ gene similar to nirQ of the denitrification gene cluster from Pseudomonas species. Gene 153, 75-79. 